\title{
THE EFFECT OF Ananas comucus EXTRACTED BROMELAIN ENZYME ADDITION UNDER DIFFERENT pH ON THE PHYSICOCHEMICAL PROPERTIES OF COTTAGE CHEESE
}

\author{
Sylvia Komansilan ${ }^{1)}$, Djalal Rosyidi*2), Lilik Eka Radiati ${ }^{2)}$, Purwadi Purwadi ${ }^{2)}$ \\ 1) Doctoral Program, Faculty of Animal Science, Universitas Brawijaya, Malang, East Java, \\ 65145, Indonesia \\ ${ }^{2)}$ Faculty of Animal Science, Universitas Brawijaya, Malang, East Java, 65145, Indonesia \\ E-mail:djalal_tht@ub.ac.id
}

Submitted 15 January 2020; Accepted 10 February 2020

\begin{abstract}
The research aims to analyse the effect of bromelain enzyme addition from Ananas comucus under different $\mathrm{pH}$ condition to the physicochemical properties of cottage cheese. The observed variables include protein, fat, moisture, ash and cheese yield. The research was conducted in a completely randomized design with 4 treatments $(\mathrm{K} 1=\mathrm{pH} 4.5 ; \mathrm{K} 2=\mathrm{pH} 4.6$; $\mathrm{K} 3=\mathrm{pH} 5.4$; and $\mathrm{K} 4=\mathrm{pH} 5.5)$ and 4 replications. All of the data were analysed with analysis of variance (ANOVA) and followed with least significant difference (LSD) test. The results showed that the bromelain addition under $\mathrm{pH} 4.6$ showed the best physicochemical properties of cottage cheese that had lowest fat content $(0.67 \pm 0.53 \%)$ and highest yield $(18.15 \pm 0.22$ $\%$ ) compared to other $\mathrm{pH}$ condition, while the protein and ash content did not show any significant difference on all $\mathrm{pH}$ condition.
\end{abstract}

Keywords: Enzyme; cheese; bromelain; yields 


\section{INTRODUCTION}

Cheese is one of the processed milk products which contained high nutrients and become a preferred food products in Indonesian market. Cheese is commonly used both as the main dish or food flavouring agent. According to Mirza and Mulyani (2013), the cheese consumption in Indonesia has increased for $5.99 \%$ in 2001 to 2002 with the total cheese consumption around the y reached 5,127.58 tonnes as reported by PT. Kraft Indonesia. Moreover, the Indonesia has imported $7,869.67 \mathrm{~kg}$ of fresh cheese on 2010, and increased to $10,357.98 \mathrm{~kg}$ in 2011 . The data showed that the demand for cheese product has increased as much as $2,488.31 \mathrm{~kg}$ a year or $207,359 \mathrm{~kg}$ monthly. The high consumption for cheese products thus demand a higher production of cheese as well. A sustainable cheese production by utilizing local resources starting from the milk as the main ingredients and enzyme for the cheese production offers a promising solution to meet the demand.

Enzyme is a group of protein that biologically catalyse chemical reactions such as hydrolysis, oxidation, reduction, isomerase, carbon chain cleavage and radical transfer (Sumardjo, 2006). The chemical reaction catalysed by an enzyme would be thousand times more optimal, while the catalysis could occur on wide range of $\mathrm{pH}$ condition and temperature with the reaction is commonly specific and selective to certain substrates (Chang, 2005). One of an important enzymes for cheese production is proteolytic enzyme. On cheese production, rennet enzyme is widely used as it contained rennin which has proteolytic abilities and chymosin as with the coagulating ability. However, research has been done to find another potential proteolytic enzyme to be an alternative for rennet enzyme.

Ananas comosus or pineapple has been known as a cheap and widely available source for bromelain enzyme, an enzyme that is commonly used to tenderize a meat by breaking down the protein bonds. However, aside for tenderizing meat, the application of bromelain enzyme is still limited, especially for milk or cheese products even though it is a proteolytic enzyme. The utilization of bromelain enzyme from Ananas comusus would provide a safer alternative for rennet enzyme as it is originated from a plant, while also added with its relatively cheap price compared to the synthetic protelolytic enzyme.

The bromelain enzyme would catalyse proteolysis by hydrolysing protein into amino acids. The enzyme would also help milk coagulation, which is one of essential steps in cheese production. The cheese production would be affected by $\mathrm{pH}$, temperature, time of incubation and enzyme addition (Kapoor and Metsger, 2008). Previous research by Jaya and Hadikusuma (2009) showed that the utilization of Ananas comusus bulb and skim could be used for cottage cheese production which had 10.34 to $12.77 \%$ protein, 70.5 to $85.78 \%$ moisture, $\mathrm{pH}$ at 4.36 to 4.75 , and 11.85 to $15.77 \%$ cheese yield.

However, research on the utilization of bromelain enzyme from Ananas comusus extract for cheese production is still limited. In this research we aimed to observe the effect of Ananas comosus extracted bromelain enzyme under different $\mathrm{pH}$ condition to the physicochemical properties
*Corresponding author:

Djalal Rosyidi

Email: djalal_tht@ub.ac.id

Faculty of Animal Science, Universitas Brawijaya, Malang, East Java, 65145, Indonesia
How to cite:

Komansilan, S., Rosyidi, D., Radiati, L. E., \& Purwadi, P. (2020). The Effect of Ananas comucus Extracted Bromelain Enzyme Addition Under Different $\mathrm{pH}$ on the Physicochemical Properties of Cottage Cheese. Jurnal Ilmu Dan Teknologi Hasil Ternak, 15(1) 38-45 
of cottage cheese. The Ananas comusus used in this research is originated from Kotamobagu, North Sulawesi Province. The province has been known as the main producers of Ananas comosus, the results of this research is then expected to also contribute on the knowledge of local resource utilization and product diversification for cheese production.

\section{MATERIALS AND METHODS}

The research was conducted in the Laboratory of Animal Products Technology, Faculty of Animal Science, Brawijaya University for the cheese production and cheese yield analysis and Laboratory of Food Technology, Faculty of Agricultural Technology, Brawijaaya University for the chemical analysis.

\section{Materials}

The materials used in this research include cottage cheese, crude bromelain enzyme extracted from Ananas comusus, fresh dairy milk. The equipment for cheese production include plastic container, whey container, heater, thermometer, gauze filter, mixer, and $\mathrm{pH}$ meter.

\section{Methods \\ Cottage cheese production}

The crude bromelain enzyme extraction from Ananas comusus and procedure for cottage cheese production is presented in Figure 1 and 2, respectively. The cottage cheese was made by firstly pasteurize $28 \mathrm{~L}$ of dairy milk at $70^{\circ} \mathrm{C}$ for 15 min (High Temperature Short Time/HTST pasteurization). The milk was then cooled down until reached $40^{\circ} \mathrm{C}$ and conditioned for the $\mathrm{pH}$ according to the treaments then added with bromelain enzyme as much as $3 \%(\mathrm{w} / \mathrm{w})$. The milk was then incubated for $35 \mathrm{~min}$ and filtered through gauze filter and added with $1 \%(\mathrm{w} / \mathrm{w})$ salt. The curd was then incubated at $-17^{\circ} \mathrm{C}$ for $24 \mathrm{~h}$ before analysed.



Figure 1. Crude extraction of bromelain enzyme from Ananas comucus (Manoi, 2007)

\section{Protein}

The protein content was analysed by using Kjeldahl method (AOAC, 2005). As much as $3 \mathrm{~g}$ of cottage cheese was ground and placed in $30 \mathrm{~mL}$ Kjeldahl flask and added with $5 \mathrm{~g} \mathrm{Na}_{2} \mathrm{SO}_{4}, 20 \mathrm{~mL} \mathrm{H}_{2} \mathrm{SO}_{4}$ and $0.2 \mathrm{gr} \mathrm{CuSO}_{4}$. The solution was then boiled for 3 to $4 \mathrm{~h}$ until became transparent. The flask was then cooled down and placed into distiller, added with $100 \mathrm{~mL}$ aquadest and 60 $\mathrm{mL}$ of $45 \% \mathrm{NaOH}$. The flask was heated again, added with $50 \mathrm{~mL}$ HCL $0.1 \mathrm{~N}$ until turned to pink colour. The blank standard was done with the same procedure. 


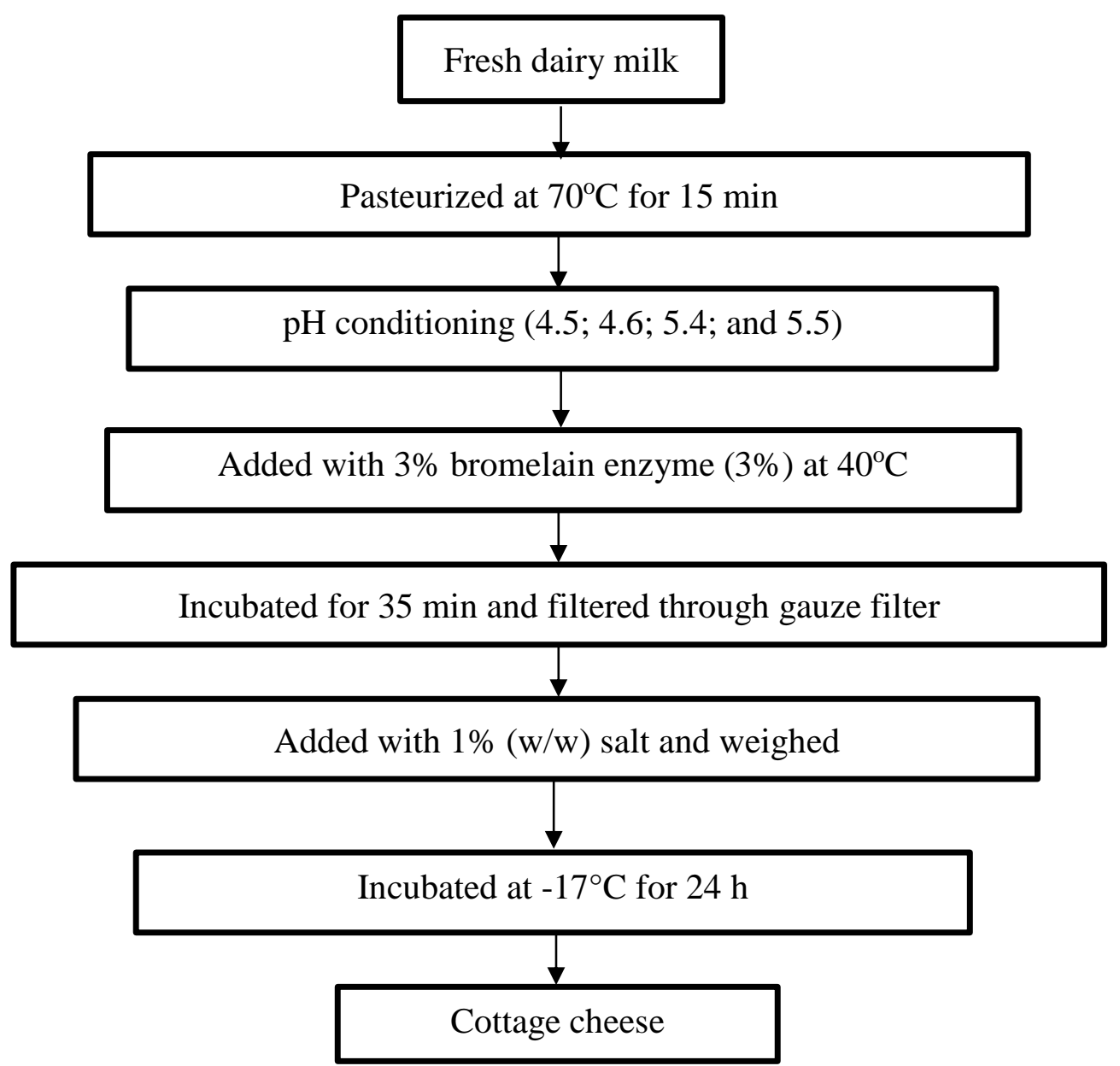

Figure 2. Cottage cheese production

Fat

The fat content was analysed by following AOAC (2005). The boiling flask was firstly heated on the oven at $105^{\circ} \mathrm{C}$ and then weighed after cooled down in the desiccator. As much as $5 \mathrm{~g}$ of dry sample was placed into the filter paper and then into the Soxhlet extractor. A condenser was then placed above the boiling flask. Hexane solvent was added to the boiling flask accordingly.

Sixteen hours reflux was then performed until the sample solution turned clear color. The extracted sample was then dried in the oven for $105^{\circ} \mathrm{C}$ to evaporate any solvent residue and reached a constant weight. The sample was then cooled in the desiccator and weighed. The fat content is measured by the following formula:

\section{Moisture}

The moisture was analysed by following AOAC (2005). The sample was dried in the oven at $100-105{ }^{\circ} \mathrm{C}$ for $3-5 \mathrm{~h}$. The sample was then cooled down on the desiccator for $30 \mathrm{~min}$. The initial weight and final weight of the sample was then recorded to be calculated by the following formula:

$$
\begin{gathered}
\text { Protein }(\%)=\frac{\mathrm{mL} \mathrm{NaOH}-\mathrm{mL} \text { sample } \times 14 \times 6.25}{\text { Sample weight }} \times 100 \% \\
\text { Fat }(\%)=\frac{\mathrm{C}-\mathrm{B}}{\mathrm{A}} \times 100 \%
\end{gathered}
$$

A = Sample weight $\quad B=$ Initial boiling flask weight $\quad$ C $=$ Final boiling flask weight 


$$
\text { Moisture (\%) }=\frac{\text { Initial sample weight }- \text { final sample weight }}{\text { Final sample weight }} \times 100 \%
$$

Ash

The petri dish was heated at $400^{\circ} \mathrm{C}$ for $1 \mathrm{~h}$, and then weighed after cooled down on the desiccator for $1 \mathrm{~h}$ (A). The cheese sample for $5 \mathrm{~g}$ was heated for $400^{\circ} \mathrm{C}$ along with the petri dish for $1 \mathrm{~h}$, the sample along with the petri dish was then weighed after cooled down on the desiccator (B). The ash content is calculated as follow (AOAC, 2005):

\section{Cheese yield}

The cottage cheese texture was measured by using Penetrometer (ShakeelUr-Rehman et al., 2003). The texture was then calculated by the following formula:

$$
\begin{gathered}
\text { Ash (\%) }=\frac{\mathrm{B}-\mathrm{A}}{\text { Sample weight }} \times 100 \% \\
\text { Yield (\%) }=\frac{\text { Final product weight }}{\text { total Ingredients weight }} \times 100 \%
\end{gathered}
$$

\section{Data analysis}

The research was conducted as laboratory experiment in a completely randomized design with 4 treatments $(\mathrm{K} 1=\mathrm{pH} 4.5 ; \mathrm{K} 2$ $=\mathrm{pH} 4.6 ; \mathrm{K} 3=\mathrm{pH} 5.4 ;$ and $\mathrm{K} 4=\mathrm{pH} 5.5$ ) and 4 replications. All of the data were analysed with analysis of variance (ANOVA) and followed with least significant difference (LSD) test by using SPSS 16.0 software (Subali, 2010).

\section{RESULTS AND DISCUSSIONS}

The physicochemical properties of the cottage cheese in this research, which include protein, fat, moisture, and ash content as well as cheese yield is presented in Table 1.

\section{Different pH to protein content of cottage cheese}

The analysis of variance showed that different $\mathrm{pH}$ condition did not give significant effect $(\mathrm{P}>0.05)$ to the protein content of cottage cheese. This can be seen from the relatively similar protein content of the cottage cheese (Table 1). In this research, the highest protein content was achieved in K2 (16.88 \%), followed with K4 $(16.72 \%)$ and K3 (16.04 \%), while the lowest was shown on K1 (16.02\%). The protein content in cheese is categorized as easily digested protein due to the protein breakdown during the cheese production. The increased protein content was caused by the addition of Ananas comosus which contained protein coagulating agent. Moreover, Ananas comosus contained bromelain enzyme, a proteolytic enzyme which hydrolyse protein into amino acids. According to Purwadi (2010) incorrect acid addition during cheese production could cause mushy curd and loss of whey. In this research, the protein content has fulfilled the standard for cottage cheese (12.70 to $21.00 \%$ ).

\section{Different pH to fat content of cottage cheese}

The analysis of variance showed that different $\mathrm{pH}$ give a highly significant effect $(\mathrm{P} \leq 0.01)$ to the fat content of cottage cheese. Fat content was decreased along with bromelain enzyme addition. The lowest fat content was found in $\mathrm{K} 2$, this indicates that at $\mathrm{pH}$ 4.6, the bromelain enzyme has met its isoelectric condition. This would initiate higher fat dissolve and thrown away along with whey during pressing of the cheese. Cottage cheese with the highest fat content 
in this research was found in $\mathrm{K} 4(3.22 \%)$, followed with K3 $(2.47 \%)$ and K1 (192\%), while the lowest was found in $\mathrm{K} 2(0.67 \%)$. The maximum fat content of cottage cheese according to USDA (2001) is $0.5 \%$. This showed that the only cottage cheese that fulfilled the standard was K2. Sukotjo (2003) added that cottage cheese is categorized as low fat soft cheese, thus the fat content of cottege cheese is one of essential parameters to determine its quality.

\section{Different pH to moisture of cottage cheese}

The analysis of variance showed that different $\mathrm{pH}$ gave a highly significant effect $(\mathrm{P} \leq 0,01)$ to the moisture of cottage cheese. Cottage cheese with the lowest moisture in this study was found in K1 (56.33 \%), followed with K2 (57.23\%) and K3 (57.80 $\%$, while the highest was found at $\mathrm{K} 4$ $(58.48 \%)$. The low $\mathrm{pH}$ would cause acidic environment which pull out the whey protein from the curds, and the breakdown of protein bond with hydrogen will be filtered. On the other hand, the high $\mathrm{pH}$ would contain higher moisture. The different moisture of cottage cheese in this study was due to several factors, which were: (1) bound water in the curd structure; (2) bound water on hygroscopic particles in curd; and (3) free water. Lobato et al. (2007) added that higher protein content in cheese would increase the casein matrix capabilities to bind water (Lobato et al., 2007).

Tabel 1. Physicochemical properties of cottage cheese

\begin{tabular}{lcccc}
\hline Physicochemical & \multicolumn{4}{c}{ Treatments } \\
\cline { 2 - 5 } \multicolumn{1}{c}{ properties } & K1 & K2 & K3 & K4 \\
\hline Protein $(\%)$ & $16.02 \pm 0.548$ & $16.88 \pm 0.87$ & $16.04 \pm 0.80$ & $16.72 \pm 0.26$ \\
Fat $(\%)$ & $1.92 \pm 0.40^{\mathrm{b}}$ & $0.67 \pm 0.53^{\mathrm{a}}$ & $2.47 \pm 0.52^{\mathrm{ab}}$ & $3.22 \pm 0.76^{\mathrm{b}}$ \\
Moisture (\%) & $56.33 \pm 0.60^{\mathrm{a}}$ & $57.23 \pm 0.74^{\mathrm{ab}}$ & $57.80 \pm 0.73^{\mathrm{bc}}$ & $58.48 \pm 0.84^{\mathrm{c}}$ \\
Ash $(\%)$ & $1.61 \pm 0.55$ & $0.72 \pm 0.39$ & $1.10 \pm 0.51$ & $1.34 \pm 0.50$ \\
Yield $(\%)$ & $16.68 \pm 0.29^{\mathrm{c}}$ & $18.15 \pm 0.22^{\mathrm{d}}$ & $15.36 \pm 0.01^{\mathrm{b}}$ & $14.00 \pm 0.004^{\mathrm{a}}$ \\
\hline
\end{tabular}

Description: Different superscripts indicate significant difference on different $\mathrm{pH}$ conditions $(\mathrm{P} \leq 0.01) . \mathrm{K} 1=\mathrm{pH} 4.5 ; \mathrm{K} 2=\mathrm{pH} 4.6 ; \mathrm{K} 3=\mathrm{pH} 5.4 ;$ and $\mathrm{K} 4=\mathrm{pH} 5.5$.

\section{Different $\mathrm{pH}$ to ash content of cottage cheese}

The analysis of variance showed that different $\mathrm{pH}$ did not give significant effect ( $P>0.05$ to the ash content of cottage cheese. As presented in Table 1, the ash content of cottage cheese produced under different $\mathrm{pH}$ condition are relatively similar. The lowest ash content of cottage cheese in this study was found in $\mathrm{K} 2(0.72 \%)$, followed with $\mathrm{K}$ 3 (1.10) and K4 (1.34\%), while the highest was found in K1 $(1.61 \%)$. Moreover, the ash content of cottage cheese in this study has fulfilled the standard at around 0.21 to $1.10 \%$.

\section{Different pH to cottage cheese yield}

The analysis of variance showed that different $\mathrm{pH}$ gave a highly significant effect $(P \leq 0,01)$ to the yield of cottage cheese. The lowest yield was found in K4 (14.00\%), followed with K3 (15.36\%) and K1 (16.68 $\%$ ), while the highest was found in $\mathrm{K} 2$ $(18.15 \%)$. Cheese yield indicates the amount of produced cheese from the total input during cheese production, which include milk, bacterial started and salt (McSweeney, 2007). The different cheese yield in this study was due to the different casein coagulation, which mainly determined from the $\mathrm{pH}$ condition. Moreover, the bromelain enzyme addition also contributes to the casein coagulation process. Geantaresa and Supriyanti (2010) showed that protease enzyme will breakdown k-casein (kappa casein) in the surface area of casein micelle into para-kappa-casein. Moreover, when the $\mathrm{pH}$ is closer to the casein isoelectric $(\mathrm{pH} 4.6$ to 4.7), the casein micelles will be coagulated into gel through hydrophobic 
interaction. Pardede et al. (2013) added that calcium also contributes to the casein coagulation by aggregating the casein micelles.

\section{CONCLUSION}

The research concludes that $3 \%$ bromelain enzyme addition at $\mathrm{pH} \quad 4.6$ produced the best physicochemical properties of cottage cheese.

\section{REFERENCES}

AOAC. (2005). Analysis of Official Analytical Chemestry Methods (18th ed.). Washington, DC.

Chang, R. (2005). Kimia Dasar: Konsepkonsep Inti (2nd ed.). Jakarta: Erlangga.

Geantaresa, E., \& Supiryanti, F. T. (2010). Pemanfaatan ekstrak papain sebagai bagai koagulan pada pembuatan keju cottage menggunakan bakteri. Jurnal Sains dan Teknologi Kimia, 1(1), 38-43.

Jaya, F., \& Hadikusuma, D. D. (2009). The effect of cow s milk substitution with soybean s milk and the concentration rate of ananas comosus extract addition to cottage cheese physical and chemical quality. Jurnal Ilmu Dan Teknologi Hasil Ternak, 4(1), 46-54.

Kapoor, R., \& Metzger, L. E. (2008, March). Process cheese: Scientific and technological aspects - A review. Comprehensive Reviews in Food Science and Food Safety. https://doi.or $\mathrm{g} / 10.1111 / \mathrm{j} .1541-4337.2008 .00040 . \mathrm{x}$

Lobato-Calleros, C., Reyes-Hernández, J., Beristain, C. I., Hornelas-Uribe, Y., Sánchez-García, J. E., \& VernonCarter, E. J. (2007). Microstructure and texture of white fresh cheese made with canola oil and whey protein concentrate in partial or total replacement of milk fat. Food Research International, 40(4), 529537. https://doi.org/10.1016/j.foodres. 2006.10.011

Manoi, F. (2007). Ekstrak ampas nenas sebagai medium campuran pada pembuatan nata de cashew. Buletin Penelitian Tanaman Rempah Dan Obat, 18(1), 107-116. https://doi.org /10.21082/bullittro.v18n1.2007.\%p

McSweeney, P. (2007). Cheese Problems Solved. England: CRS Press.

Mirza, D. M. E., \& Mulyani, S. (2013). Produksi alkohol dari hasil sampingan pembuatan keju (whey) yang disubsitusi dengan limbah cair yang difermentasi oleh S. cerevisae. Jurnal Aplikasi Teknologi Pangan, 2(2), 80-86.

Pardede, B. E., Adhitiyawarman, \& Arreneuz, S. (2013). Pemanfaatan enzim papain dari getah buah pepaya (Carica papaya L) dalam pembuatan keju cottage menggunakan bakteri Lactobacillus bulgaricus. Jurnal Kimia Khatulistiwa, 2(3), 163-168.

Purwadi. (2010). Physical quality of mozzarella cheese produced by lime juice as an acidifier. Jurnal Ilmu Dan Teknologi Hasil Ternak, 5(2), 33-40.

Shakeel-Ur-Rehman, Farkye, N. Y., \& Yim, B. (2003). Use of dry milk protein concentrate in pizza cheese manufactured by culture or direct acidification. Journal of Dairy Science, 86(12), 3841-3848. https://doi.org/ 10.3168/jds.s0022-0302(03)7 3991-5

Subali, B. (2010). Analisis Statistika Menggunakan program SPSS Aplikasinya dalam Rancangan Percobaan. Universitas Negeri Yogyakarta. 
Sukotjo, S. (2003). Proses Pembuatan Keju Lunak. Institut Teknologi Indonesia.

Sumardjo, D. (2006). Pengantar Kimia. In Buku Panduan Kuliah Mahasiswa Kedokteran dan Program Strata I Fakultas Bioeksakta. Jakarta: Penerbit Buku Kedokteran EGC.
USDA. (2001). Specification for Cottage Cheese and Dry Curd Cottage Cheese. Agricultural Marketing Service USDA. 